\title{
The Effect of Fluoride and Aluminum on the Anion Exchange of Plutonium from Nitric Acid
}

\author{
S. Fredric Marsh
}

\begin{abstract}
DISCLAIMER
This report was prepared as an account of work sponsored by an agency of the United States Government. Neither the United States Government nor any agency thereof, nor any of their employees, makes any warranty, express or implied, or assumes any legal liability or responsibility for the accuracy, completeness, or usefuiness of any information, apparatus, product, or process disclosed, or represents that its use would not infringe privately owned rights. Reference herein to any specific commercial product, process, or service by trade name, trademark, manufacturer, or otherwise does not necessarily constitute or imply its endorsement, recommendation, or favoring by the United States Government or any agency thereof. The views and opinions of authors expressed herein do not necessarily state or reflect those of the Inited States Government or any agency thereof.
\end{abstract}
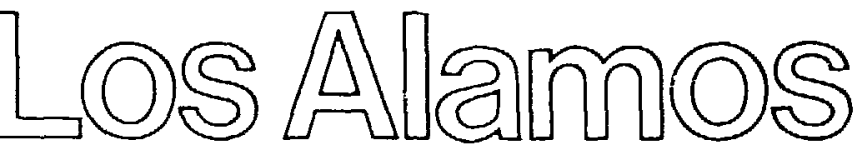

Los Alamos National Laboratory Los Alamos,New Mexico 87545 


\title{
THE EFFECT OF FLUORIDE AND ALUMINUM ON THE ANION EXCHANGE OF PLUTONIUM FROM NITRIC ACID
}

\author{
by
}

\author{
S. Fredric Marsh
}

\begin{abstract}
Anion exchange in nitric aciò is a prominent aqueous process used to recover and purify plutonium from impure nuclear materials. This process is sensitive to fluoride ion, which complexes plutonium in competition with the anionic nitrato complex that is strongly sorbed on the anion exchange column. Fluoride interference traditionally has been counteracted by adding a masking agent, such as aluminum, that forms competing complexes with fluoride. The interfering effect of fluoride is known to be a function not only of the fluoride-to-aluminum ratio but also of the fluoride-to-plutonium ratio, yet no comprehensive study of this three-component system has previously been reported. This report summarizes a Los Alamos study of the effect of 25 fluoride-aluminumplutonium combinations on the anion exchange sorption of plutonium. Five aluminum-to-plutoniusn ratios ranging from 0.10 to 10 were each evaluated at five fluoride-to-aluminum ratios that ranged from 0 to 6 . The fluoride-to-plutonium ratio has a greater influence on plutonium sorption than does the fluoride-to-aluminum ratio. Aluminum was less effective as a masking agent than had been assumed, because measurable fluoride interference occurred at all levels of added aluminum.
\end{abstract}

\section{INTRODUCTION}

Anion exchange in nit ric areid is the principal aqueous process 11 sect to recover and purify plutonium at the Los Alannos Plutominnu Facility. A Los Alannos dovelopment affort directed at improving this process hat: resilt end in (1) the rephlacenont of provionsly used yol-type resin with marroperoms resin. ${ }^{1}$ (2) an intproved fered treat ment procedure that neses only hy-

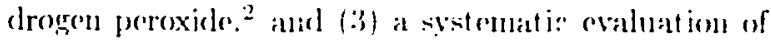
the effece of plat onium concent ration and solution flow rate on the effection capacity of the seldected macroporous rosin."
Aqueous ford solutions used in this process always contain Huoride. whish is required to dissolve refractory plutonium oxide ferd materials at an aceptable rate. Fluoride also is required to dissolve the large quantities of silicate materials often found in plut onimun-contaminated scrap mat erials.

Fluoride acederates the dissolution of difficult-todissolve conpounds of plutonium beratse it forms highly stable complexes with plut onium. The anion exrhange separation that follows. however. depends on the anionic nit rato complex of phet onium that st rongly sorles on the resin. Hence. the plut oninum fluoride conplex that is an assot during dissolution is a liability 
Juring the subsequent anion exchange separation because it interferes with formation of the plutonimm nitrate complex.

Fluoride interference can be reduced by adding a masking agent known to form a competing. highstability, soluble fluoride complex. Aluminum conmonly is added to plutonium feed solutions for this purpose. The resulting solutions contain plutonium, fluoride, and aluninum in relative anounts that vary over wide ranges. The many competing equilibria involved in such solutions make subsequent anion exchange behavior of plutonium difficult to predict.

Interference by fluoride during the processing of plutonium by anion exchange is known to be a function of not only the fluoride-to-plutonium ratio but also the aluminum-to-fluoride ratio. Aluminum commonly has been added to mask the interference of fluoride during most of the nearly thirty years that nitrate anion exchange has been ased to purify plutonium. Yet we are unable to find a published, systematic study of the effect of specific quantities of aluminum and fuoride on the plutonium anion exchange process. Our investigation provides this previously unavailable information. which should facilitate the processing of fluoridecontaining solutions of plutominn.

\section{EXPERIMENTAL}

\section{Experimental Design}

Plutonium. The plitunium . oncentration was maintained at a constant level of four grams per liter throughont this series of experiments. The oxidation state of all plutonium used in this study was adjusted to Pu(IV) with hydrogen peroxide. ${ }^{2}$ after which the absence of $\mathrm{Pu}(\mathrm{VI})$ and $\mathrm{Pu}$ (III) was confirmed by spectrophotomet ric analysis.

Aluminum. Five levels of aluminum, relative to plutonium. were obtained by adding appropriate quantities of $2.2 \mathrm{M}$ aluminum nitrate solution. The selected aluminnm-to-plutonium mole ratios were 0.10. 0.33. 1.0. 3.0. and 10 .

Fluoride. Fluoride was arlded, as hydrofluoric acid. to provide five Huoride-to-aluminum ratios at cach level of aluminum to phlutanium. The selected molo ratios of fluoride io aluminum were 0.1 .5 .3 .0$. 4.5. and 6.0.

Nitric Acid. Sufficient nitric arid and water were adderl to maintain the total acid concentration at $7 \mathrm{M}$. (The small amount of hydrogen ion present as hydrofluoric acid was included in the calculation of total acid concentration.)

Nitrate. Because aluminum was added as the aluminum nitrate salt, three moles of additional nitrate were added with every mole of aluminum. This provided additional nitrate that contributed to a varying total nitrate concentration in excess of the nitrate present as $7 M$ nitric acid.

Resin. Lewatit MP-500-FK (40- to 70-mesh) macroporous anion exchange resin (obtained from $M$ bay Chemical Company, Philadelphia, Pennsylyania) was used in this study. Individual 10-milliliter portions of these solutions were contacted with portions of air-dried, nitrate-form Lewatit resin. A weigher amount of air-dried resin that corresponded to a 2-milliliter volume of nitrate-form resin in water was taken for each contact. (The specified volume of wet resin weighed 0.66 gram in air-dried form.)

\section{Assay Technique}

Dynamic batch contacts of each combination of solution and resin were achieved using a wrist-action shaker. Each solution initially contained the selected quantities of plutonium, aluminum, and fluoride. After each dynamic contact period, a measured portion of solution was removed for assay of plutonium using gamma spectrometry, by assaying the $129-\mathrm{keV}$ gamma ray of ${ }^{239} \mathrm{Pu}$.

After the first dynamic contact period was completed, the shaker was stopped only long enough to remove a solution aliquot for radioassay. The dynamic contact was quickly resumed until the second contact period had been completed, after which another aqueous portion was removed for assay. This procedure was repeated until three aqueous portions had been rernoved for assay after dynamic contact periods of I0, 20, and 60 minutes.

The fraction of initial plutonium in each contacted solution was calculated relative to the quantity of ${ }^{239} \mathrm{P}_{11}$ in an identical portion of uncontacted solution. From these data. plutoniurn distribution coefficients were calculated for three contact periods at each of the 25 Huoride-to-aluminum-to-plutonium ratios. Sequential measurements for multiple contact periods provided important sorption kinetics data for the plutonium nitrato complex. whose sorption rate is known to be particularly slow.

Distribution coefficients (Kd) were calculated as follows: 
$\mathrm{Kd}=\frac{\text { concentration of element per milliliter of wet resin }}{\text { concentration of element per milliliter of solution }}$.

In practice. Kat walues were calculated ly the reguation:

$$
\text { Iíl }=\left[\left(\begin{array}{ll}
A_{t} & A_{1}
\end{array}\right) / A_{l}\right] /\left(V_{l} / V_{r}\right)
$$

where

$A_{t}$ is the activity of the actinide initially in the licpuid. $A_{l}$ is the actinide activity in the liquid after cont ant.

$V_{l}$ is the liquid volume, and

$V$, is the volume of wet resin.

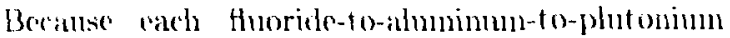
combination was nsed for a series of three sequen tial contact measurements. Ho liquidl-to-resin ratio chamged as rach aquerous portion was removere for inisay. We corrected for this rlanging ratio as well at for the clecrease in the total activity remainin:s iu the vial after the removal of each aqueous portion.

We elected to express Kol in terms of wet-resin volume. contrary to the common practice of expressing Kol in terms of dry-resin weiglit, for reasons explained in cletail in a previons report.' Whichever convention is used. however. the relative effect of fluoride and aluminnem remains ilor same.

\section{RESULTS AND DISCUSSION}

All solutions need in this st nely were prepared to initially cont ain the appropriate anomuts of Huoride. aluminmm. nitric acid, and resin. Plutonium was added last, immediately before the dynamic contact began. Under normal rireumstances, the olive green color of the plutonium nitrate complex appears promptly when $\mathrm{Pu}(\mathrm{IV})$ is added to $7 M$ nitric acid. When plutonium was added to these solutions that containcel varying ratios of fluoride and aluminum. however. a wide range of colors was observed. Some solutions showed the expected green color. some showed a lighter shade of green. and some showel un green. The intensity of the green color indicate: the concentration of pluter nimn nit rate complex remaining in solution, and thus. the extent of fluoride interference in eiach casee.

Beranse the maximum aluminum-to-plutonium ratio was 10 and the naximum fluoride-to-aluminum ratio was 6 . the highest fluoride-to-plutonium ratio in this study was $6($ ). At this maxinum fluoridlo-toplutonium ratio. and in a fow other solutions where the fluoride-to-phitonium rat io wis high. the expected green color of the plutonium nitrate complex was cither absent or quite pale. Furthermore, in those solutions in which the fluoride-to-plutonimm ratio was 60) or 45. a straw-colored precipitate, assumed to be $\mathrm{PuF}_{4}$, wati olsorved.

If plutonimn were being precipitated from certain solutions, in competition with removal from solution by ion exchange processes, an assay of phutonimm remaining in the liquid portion after the confact would serionsly overestimate the quantity of plufoniurin sorbed on the resin.

The total alssence of green color in certain highHuoride solut ions confirmed that the fluoride level was sufficient to prevent formation of the plutonium nitrate complex. In the three solutions in which precipitate formation precluded measurement of the quantity of plutonimn sorbed on the resin, we can conficlonly conclude that fluoricle interference was severe, 'ven though we are mable to provide quantitative values.

\section{Experimental Data}

The experimental data are presented in two formats. In Figs. 1 through 5, the ratio of alumin!umto-plutonium is held constant to ilemonstrate the effect of varying Huoride-to-aluminum ratios. In Figs. 6 through 10 , the Huoride-to-aluminum ratio is heid constant to demonstrate the effect of varying aluminumto-plutonium ratios.

Figure 1 shows that even small amounts of fluoride measurably suppress the distribution coefficient of $\mathrm{Pu}(\mathrm{IV})$ onto the resin. The interference of Huoride increases for a given fluoride-to-aluminum ratio as the fluoride-to-plutonium ratio increases, as shown in Figs. 1 through 5 . (The fluoride-toplutonium ratio is the product of the fluoride-toaluminum ratio and the aluminun-to-plutonium ratio in Figs. 1 through 5.)

Figure 6 shows the effect of increasing levels of aluminum nitrate when fluoride is absent. The increasing distribution cocfficient of $\mathrm{Pu}$ (IV) at the higher aluminum-to-plutonium ratios is attributed to the inareasing concentration of nitrate ion present as aluminum nitrate. In the maximum case of $\mathrm{Al} / \mathrm{Pu}=10$. the concentration of additional nitrate ion is $0.5 \mathrm{M}$.

Figures 7 through 10 present the same data shown in Figs. 1 throngh 5 in a different format. These figures show the effect of increasing tot al amounts of fluoride when the Huoride-to-aluminum ratio is held constant. The increasing interforence of fluoride at the higher fluoride-to-plutonium ratios is apparent. (The 

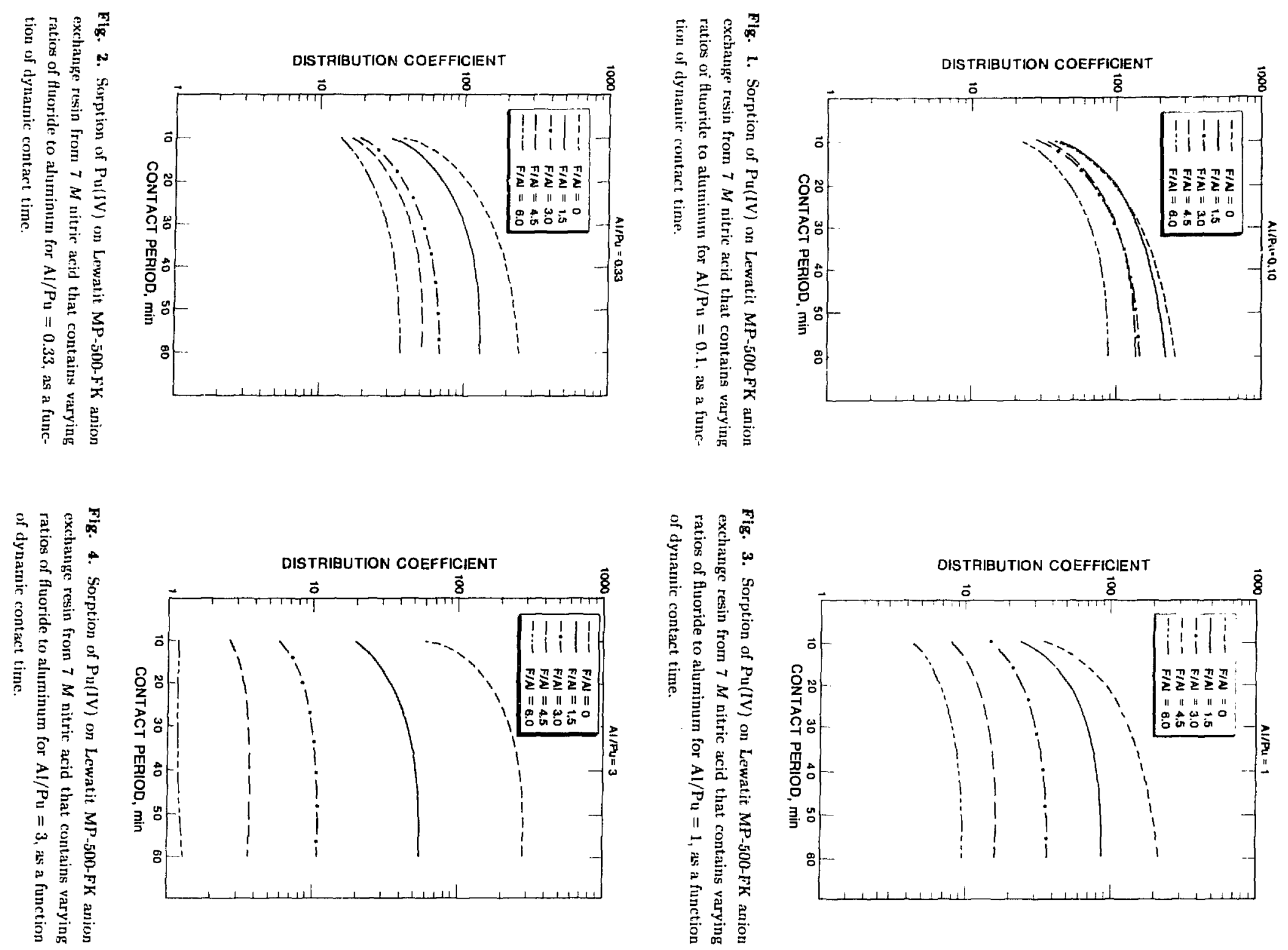


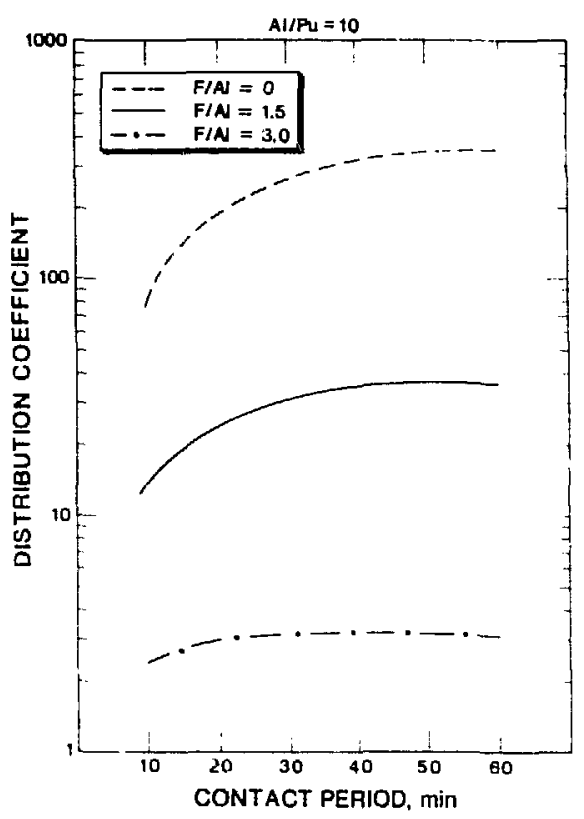

Fig. 5. Sorption of $\mathrm{Pu}(\mathrm{IV})$ on Lewatit MP-500-FK anion exchange resin from $7 M$ nitric acid that contains varying ratios of that a ide to aluminum for $\mathrm{Al} / \mathrm{Pu}=10$, as a function of dynamic contact time.

fluoride-to-plutonium ratio may be calculated as previously explained for Figs. 1 through 5.) Figures 9 and 10 show the almost total interference of fluoride in solutions in which $\mathrm{Al} / \mathrm{Pu}=3$. Precipitation prevented measurement of distribution coefficients at the bighest levels of fluoride in solutions for which $\mathrm{Al} / \mathrm{Pu}=10$, as shown in Figs. 9 and 10.

\section{CONCLUSIONS}

1. Ail levels of fluoride tested measurably suppress the distribution coefficient of plutonium, no matter how much aluminum is added. Although aluminum counteracts the interference of fluoride to a large extent, some interference always occurs. Aluminum therefore is less entective for masking fluoride than had been supposed.

2. Aluminum is much more effective as a masking agent at a given fluoride-to-aluminum ratio when the fluoride-to-plutonium ratio is low, than when the fluoride-to-plutonium ratio is high. This indicates that the anion exchange sorption of plutorium is more affected by the fluoride-to-plutonium ratio than by the fluoride-to-aluminum ratio.

3. On the basis of this study, we recommend that the quantity of aluminum added be approximately equimolar with the amount of fluoride present. Even at this ratio, however, some interference is to be expected, particularly when fluoride is high relative to plutonium.

4. Exressive aluminum should be avoided, as its competition for fluoride converts soluble fluoro complexes of elements such as silicon and tungsten to insoluble oxides, which can coat ion exchange resin and plug process filters and valves.

5. We had hoped that this study would result in a general equation that would define the level of aluminum required to mask any specified amount of fluoride. Unfortunately, the complex interactions of this chemical system do not lend themselves to such simplistic interpretation. It appears, instead, that zach specific fluoride-to-plutonium ratio may require a unique amount of aluminum to effectively mask fluoride, without causing the precipitation problems described in the preceding paragraph.

We therefore are generating digitized, visible/nearinfrared spectra for all 25 solutions examined in this study. These data will be processed by modern chemometric techniques to produce an initial data base that eventually will allow us to use on-line spectrophotometric measurements as a basis for controlling and operating the anion exchange process at near-optimum efficiency. 


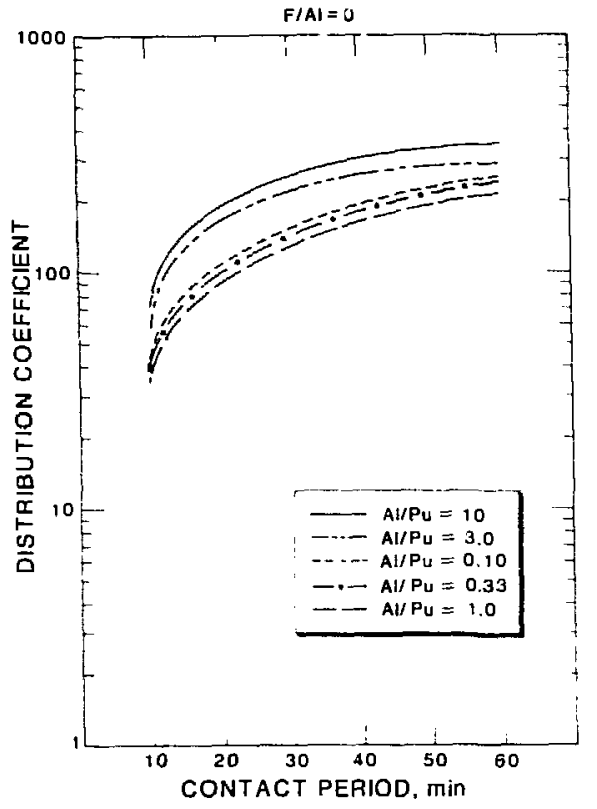

Fig. 6. Sorption of $\mathrm{Pu}(\mathrm{IV})$ on Lewatit MP-500-FK anion exchange resin from $7 \mathrm{M}$ nitric acid that contains varying ratios of aluminum to plutonium for $\mathrm{F} / \mathrm{Al}=0$, as a function of dynamic contact time.

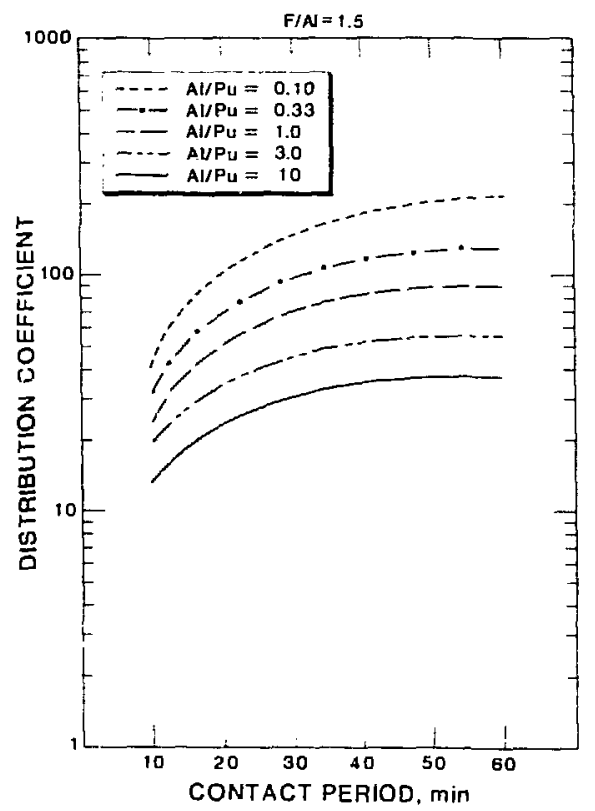

Fig. 7. Sorption of $\mathrm{Pu}(\mathrm{IV})$ on Lewatit MP-500-FK anion exchange resin from $7 \mathrm{M}$ nitric arid that contains varying ratios of aluminum to plutonium for $F / A \mid=1.5$, as a function of dynamic contact time.

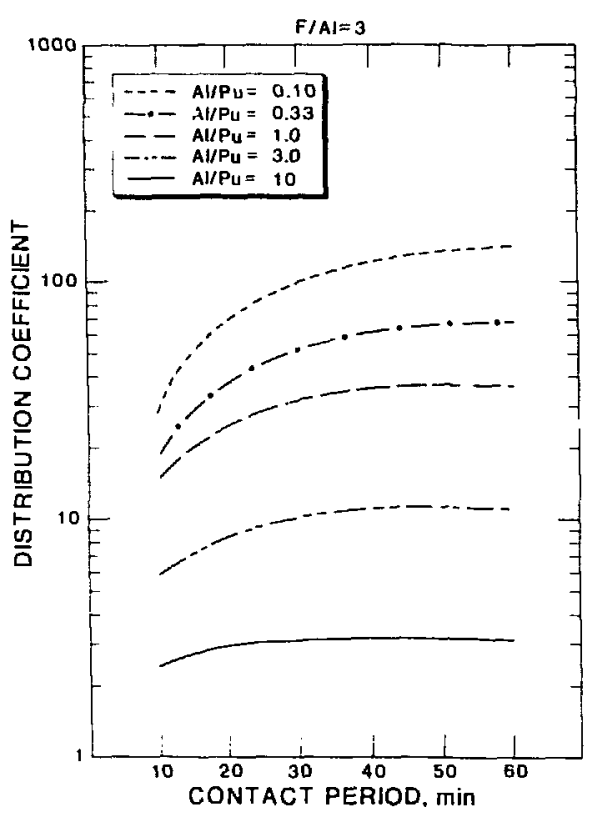

Fig. 8. Sorption of $\mathrm{Pu}(\mathrm{IV})$ on Lewatit MP-500-FK anion exchange resin from $7 \mathrm{M}$ nitric acid that contains varying ratios of aluminum to plutonium for $\mathrm{F} / \mathrm{Al}=3$, as a function of dynamic contact time.

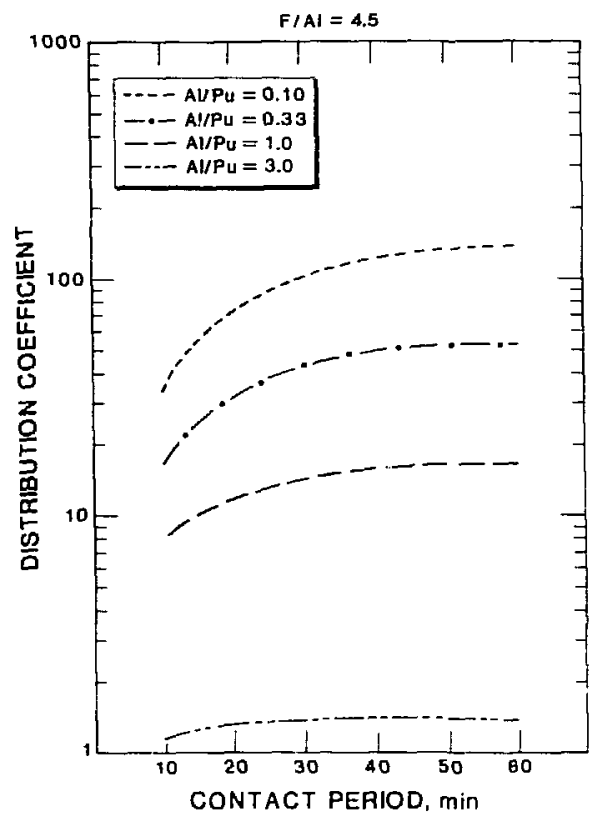

Fig. 9. Sorption of $\mathrm{Pu}(\mathrm{IV})$ on Lewatit MP-500-FK anion exchange resin from $7 \mathrm{M}$ nitric acid that contains varying ratios of aluminum to plutonium for $\mathrm{F} / \mathrm{Al}=4.5$, as a function of dynamic contact time. 


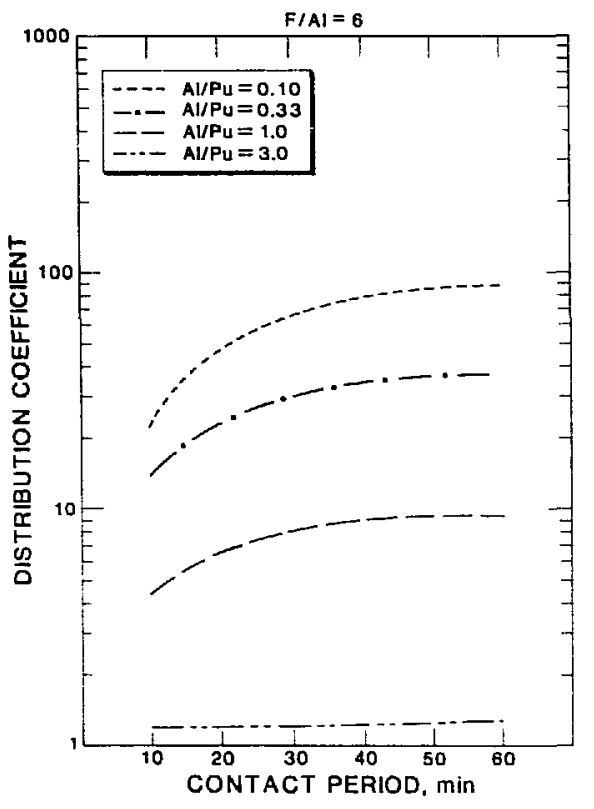

Fig. 10. Sorption of $\mathrm{Pu}(\mathrm{IV})$ on Lewatit MP-500-FK anion exchange resin from $\mathbf{T} M$ nitric acid that contains varying ratios of aluminum to plutonium for $\mathrm{F} / \mathrm{Al}=6$, as a function of dynamic contact time.

\section{REFERENCES}

1. S. F. Marsh, "Improved Recovery and Purification of Plutonium at Los Alamos Using Macroporous Anion Exchange Resin," Los Alamos National Laboratory report LA-10906 (May 1987).

2. S. F. Marsh and T. D. Gallegos, "Chemical Treatment of Plutonium with Hydrogen Peroxide Before Nitrate Anion Exchange Processing," Los Alamos National Laboratory report LA-10907 (May 1987).

3. S. F. Marsh and T. D. Gallegos, "The Influence of Plutonium Concentration and Solution Flow Rate on the Effective Capacity of Macroporous Anion Exchange Resin," Los Alamos National Laboratory report LA-10990 (July 1987). 